\title{
Persepsi Remaja Terhadap Kontrol Perilaku HIV AIDS Di Wilayah Kerja Puskesmas Parigi Tahun 2021
}

\author{
I Wayan Agus Gunawan*1, Dinar Lubis ${ }^{1}$, Luh SeriAni ${ }^{1}$ \\ ${ }^{1}$ Departemen Kesehatan Masyarakat dan Kedokteran Pencegahan, Fakultas Kedokteran , \\ Universitas Udayana
}

Author's Email Correspondence (*): iwayan_agusgunawan@yahoo.com (082189414163/08777632824)

\begin{abstract}
ABSTRAK
HIV AIDS merupakan permasalahan kesehatan yang sangat rentan berisiko terjadi pada usia remaja karena remaja masa peralihan dari anak-anak kemasa dewasa. Kabuputen Parigi Moutong merupakan daerah tertinggal yang sementara berkembang. Temuan kasus HIV AIDS serta adanya kasus penyalahgunaan narkoba pada usia remaja dikarenakan bebasnya pergaulan serta kurangnya kontrol dari orang tua. Hal ini cendrung mengakibatkan remaja berisiko terkena penyakit HIV AIDS. Tujuan penelitian ini adalah untuk mengetahui pengetahuan, sikap, norma subjektif remaja terhadap kontrol perilaku HIV AIDS di Wilayah kerja Puskesmas Parigi tahun 2021. Penelitian ini menggunakan rancangan kualitatif dengan pendekatan eksploratif. Penelitian ini dilaksanakan di Wilayah Kerja Puskesmas Parigi pada bulan April tahun 2021. Data dikumpulkan melalui metode wawancara mendalam dengan 13 informan diantaranya 8 remaja sebagai informan utama, 5 informan pendukung yang teridiri dari tiga kepala sekolah, satu petugas kesehatan dan satu orang tua remaja. Data hasil penelitian selanjutnya dianalisis dengan menggunakan metode tematik. Hasil penelitian diperoleh remaja memiliki pengetahuan yang kurang tentang HIV AIDS, sehubungan dengan efektifitas penyebaran informasi kesehatan HIV AIDS dikalangan remaja sekolah serta minat remaja untuk ingin tahu tentang HIV AIDS yang masih kurang. Remaja mempunyai sikap, norma subjektif serta persepsi yang positif terhadap kontrol perilaku HIV AIDS. Kesimpulan remaja masih memiliki pengetahuan yang kurang tentang HIV AIDS, sementara itu remaja memiliki sikap, norma subjektif dan kontrol perilaku yang positif terhadap perilaku HIV AIDS sehingga remaja dapat mencegah /menghindari perilaku HIV AIDS.
\end{abstract}

Kata Kunci: Persepsi, Remaja, HIV AIDS, Kontrol Perilaku.

Published by:

Article history :

Tadulako University

Received : 28092021

Address:

J1.Soekarno Hatta KM 9. Kota Palu, Sulawesi Tengah,

ised form : 30092021

Indonesia.

Accepted : 19102021

Phone: +628114120202

Email: Preventif.fkmuntad@gmail.com 


\begin{abstract}
HIV AIDS is a health problem that is very vulnerable to risk of occurring in adolescence because adolescents are in the transition period from children to adulthood. Parigi Moutong Regency is an underdeveloped area that is currently developing. Findings of cases of HIV AIDS and cases of drug abuse at a young age are due to free association and lack of parental control. This tends to put adolescents at risk of contracting HIV/AIDS. The purpose of this study was to determine the knowledge, attitudes, subjective norms of adolescents on HIV AIDS behavior control in the work area of the Parigi Health Center in 2021. This study used a qualitative design with an exploratory approach. This research was carried out in the Parigi Health Center Work Area in April 2021. Data were collected through in-depth interviews with 13 informants including 8 teenagers as main informants, 5 supporting informants consisting of three school principals, one health worker and one teenager's parents. The data from the research were then analyzed using the thematic method. The results of the study showed that adolescents had less knowledge about HIV AIDS, in connection with the effectiveness of disseminating HIV AIDS health information among school adolescents and their lack of interest in learning about HIV AIDS. Adolescents have positive attitudes, subjective norms and perceptions of HIV/AIDS behavioral control. Conclusions, adolescents still have less knowledge about HIV AIDS, meanwhile adolescents have attitudes.
\end{abstract}

Keywords: Perception, Youth, HIV AIDS, Behavior Control.

\title{
PENDAHULUAN
}

Penyakit Human Immunodeficiency Virus (HIV) dan Acquerid Immuno Deficiency Syndrome (AIDS) sampai saat ini masih menjadi permasalah kesehatan yang bersifat global. United Nations Programme On HIV and AIDS (UNAIDS) melaporkan pada tahun 2017 sebanyak 36,9 juta orang di dunia hidup dengan HIV AIDS. Rincian penderita diperkirakan sejumlah 35,1 juta orang dewasa,18,2 juta wanita usia 15 tahun ke atas dan sejumlah 1,8 juta anak - anak usia <15 tahun. Data kasus baru infeksi HIV pada tahun 2017 sebanyak 1,8 juta dan angka kematian kasus AIDS sebanyak 940.000 orang. (26).

Kasus HIV AIDS di Indonesia pada tahun 2017 dilaporkan sejumlah 48.300 kasus baru HIV positif dan kasus AIDS sebanyak 9.280 kasus. Pada bulan Juni 2018 terjadi peningkatan jumlah kasus baru menjadi 301.959 jiwa dan ditemukan pada umur 25-49 tahun dan 20-24 tahun.(12).

Kasus HIV AIDS yang terjadi di Provinsi Sulawesi Tengah juga dilaporkan mengalami peningkatan. Kasus HIV AIDS tahun 2018 dilaporkan jumlah pengidap infeksi HIV sebanyak 131 kasus, AIDS sebanyak 117 kasus dan pada tahun 2019 kasus HIV AIDS sebanyak 369 kasus, AIDS sebanyak 152 kasus. Secara kumulatif, kasus HIV positif sampai 
dengan tahun 2019 sebanyak 1.811 orang, jumlah kumulatif kasus AIDS sebanyak 913 orang. 393 orang diantaranya dilaporkan telah meninggal dunia.(8).

Kabupaten Parigi Moutong merupakan salah satu Kabupaten yang terdapat di Provinsi Sulawesi Tengah. Di laporkan Kasus HIV AIDS di Kabupaten Parigi Moutong mengalami peningkatan disetiap tahunnya. Kasus baru HIV positif tahun 2018 sebesar 4 kasus, dan kasus AIDS positif sebesar 15 kasus dan 4 orang diantaranya laporkan telah meninggal dunia(16).

Usia remaja merupakan tahap perubahan antara usia anak-anak menuju usia dewasa. Pada masa perkembangan ini, remaja mencapai kematangan fisik, mental, sosial dan emosional. Pada tahap perkembangan pada remaja juga dikenal dengan masa pubertas. Masa pubertas (puberty) merupakan sebuah tahapan dimana kematangan fisik berlangsung cepat, yang melibatkan perubahan hormonal dan tubuh, yang terutama berlangsung dimasa remaja awal menyatakan pada tahapan ini remaja sudah mulai berinteraksi dengan lingkungan, teman sebaya dan orang dewasa. Masa remaja mulai muncul ada rasa tertarik kepada lawan jenis, apabila dibiarkan tanpa adanya kontrol dari keluarga maupun masyarakat, remaja akan bebas berperiku merokok, penyalahgunaan narkotika serta obat-obatan terlarang (narkoba), Pecandu narkoba suntik, pacaran serta berganti-ganti pasangan akan berisiko terjangkit virus HIV AIDS (19). Adapun aktifitas pacaran pada remaja yang dapat mengarah pada HIV AIDS seperti ciuman bibir, mencium leher, meraba daerah erogen, bersentuhan alat kelamin dan melakukan hubungan seks.(20).

Dalam Teori Perilaku Terencana atau teori planned behavior (TPB) mengungkapkan bahwa perilaku itu sendiri dipengaruhi oleh niat individu terhadap perilaku tertentu. Pada tahun 1975 Fishbein dan Ajzen mengembangkan TPB menyatakan manusia berperilaku sesuai dengan akal sehatnya. Manusia memiliki pikiran berupa akal sehat sehingga manusia akan mempertimbangkan semua akibat dari perbuatan mereka sebelum melakukan perilaku. Teori planned behavior (TPB) mengatakan bahwa pengetahuan, sikap, norma subjektif dan persepsi kontrol perilaku cendrung mempengaruhi niat seseorang untuk melakukan perilaku. (13).

Penelitian yang dilakukan di Nepal tentang persepsi dan pengetahuan remaja tentang HIV AIDS, dari 117 responden menunjukkan pengetahuan remaja yang baik tentang HIV AIDS. Terkait persepsi remaja tentang penularan HIV AIDS masih salah/keliru diantaranya $(62 \%)$ responden memiliki persepsi bahwa pil kontrasepsi mencegah penularan HIV, (32\%) 
responden memiliki persepsi bahwa nyamuk dapat menularkan HIV, $(21 \%)$ responden memiliki persepsi berbagai peralatan dan handuk dan lainya dapat menularkan HIV, dan (45\%) responden memiliki persepsi bahwa seseorang yang nampak sehat tidak dapat menularkan HIV AIDS.(7).

Dari hasil pengamatan yang peneliti lakukan di Wilayah kerja Puskesmas Parigi bahwa Daerah Parigi merupakan Daerah tertinggal yang saat ini sementara berkembang serta Parigi menjadi pusat kota dari Kabupaten Parigi Moutong. Disamping itu banyaknya pendatang yang masuk ke Daerah Parigi untuk mencari pekerjaan maupun mencari sekolah. Disisi lain adanya temuan kasus HIV AIDS di Daerah Parigi serta penyalahgunaan narkoba pada usia remaja 15-24 tahun dikarenakan bebasnya pergaulan pada remaja serta kurang kontrol orang tua terhadap anaknya. Penelitian ini bertujuan untuk mengeksplorasikan persepsi remaja terhadap kontrol perilaku HIV AIDS di Wilayah Kerja Puskesmas Parigi tahun 2021.

\section{METODE}

Penelitian ini menggunakan rancangan kualitatif dengan pendekatan ekslproratif. Penelitian ini berlokasi di Wilayah Kerja Puskesmas Parigi pada bulan April tahun 2021. Data dikumpulkan melalui wawancara mendalam dengan 13 informan, yang terdiri dari 8 orang remaja sebagai informan utama, 5 orang informan pendukung yang terdiri dari tiga kepala sekolah, dan masing-masing satu dari petugas kesehatan dan orang tua remaja. Pemilihan informan dilakukan secara purposive sampling dimana pengambilan sampel didasarkan pada pertimbangan peneliti mengenai sampel yang sesuai serta dapat menjawab tujuan peneliti. Selanjutnya data dari hasil Penelitian ini dianalisis dengan menggunakan metode tematik.

\section{HASIL}

Karakteristik responden pada penelitian ini meliputi umur, jenis kelamin, pendidikan, pekerjaan, jabatan serta lama pekerjaan. Tabel 4.1 menyajikan bahwa informan utama remaja sekolah yang berjumlah delapan orang yang berjenis kelamin empat laki-laki dan perempuan yang saat ini berada di rentang usia 15- 19 tahun. Sementara itu informan pendukung berjumlah lima orang yang dominan berjenis kelamin laki-laki yang mempunyai rentang usia 27-50 tahun yang memiliki pekerjaan sebagai guru dan tenaga kesehatan. 
Tabel 1

Karakteristik Informan

\begin{tabular}{|c|c|c|c|c|c|c|c|}
\hline Informan & Kode & Umur & $\mathbf{J k}$ & Pekerjaan & Pendidikan & Jabatan & $\begin{array}{c}\text { Lama } \\
\text { Bekerja }\end{array}$ \\
\hline Remaja & I-01 & 16 thn & $\mathrm{P}$ & Pelajar & SMK & - & - \\
\hline Remaja & $\mathrm{I}-02$ & 17 thn & $\mathrm{L}$ & Pelajar & SMK & - & - \\
\hline Remaja & $1-03$ & 16 thn & $\mathrm{P}$ & Pelajar & SMA & - & - \\
\hline Remaja & I-04 & 16 thn & $\mathrm{L}$ & Pelajar & SMA & - & - \\
\hline Remaja & I-05 & 17 thn & $\mathrm{P}$ & Pelajar & SMK & - & - \\
\hline Remaja & I-06 & 17 thn & $\mathrm{L}$ & Pelajar & SMK & - & - \\
\hline Remaja & I-07 & 19 thn & $\mathrm{L}$ & Marketing & SMA & $\begin{array}{l}\text { Sales } \\
\text { Maneger }\end{array}$ & 2 thn \\
\hline Remaja & I-08 & 15 thn & $\mathrm{P}$ & Buruh & SD & - & - \\
\hline Kepala sekolah & IKP01 & 27 thn & $\mathrm{L}$ & Guru & SI & $\begin{array}{l}\text { Kepala } \\
\text { Sekolah }\end{array}$ & 5 thn \\
\hline kepala sekolah & IKP02 & 50 thn & $\mathrm{L}$ & Guru & S1 & $\begin{array}{l}\text { Kepala } \\
\text { Sekolah }\end{array}$ & 27 Thn \\
\hline Kepala sekolah & IKP03 & 48 thn & $\mathrm{L}$ & Guru & S1 & $\begin{array}{l}\text { Kepala } \\
\text { Sekolah }\end{array}$ & $23 \mathrm{Thn}$ \\
\hline $\begin{array}{l}\text { Petugas } \\
\text { Kesehatan }\end{array}$ & IPK01 & 40 thn & $\mathrm{P}$ & Bidan & D4 & $\begin{array}{l}\text { Pemegang } \\
\text { Program HIV } \\
\text { AIDS }\end{array}$ & 16 thn \\
\hline $\begin{array}{l}\text { Orang Tua } \\
\text { Siswa }\end{array}$ & IORT & 42 thn & $\mathrm{L}$ & PNS & S1 & Kabid umum & 15 thn \\
\hline
\end{tabular}

\section{Pengetahuan Remaja Tentang HIV AIDS}

Berdasarkan hasil wawancara tentang pengetahuan remaja tentang HIV AIDS dijumpai beberapa sub tema diantaranya sebagai berikut:

\section{Keterpaparan Informasi Tentang HIV AIDS}

Dari hasil wawancara mendalam kepada 8 informan remaja hampir semua remaja pernah mendengar kata HIV AIDS tapi tidak pernah membaca tentang HIV AIDS namun ada beberapa informan remaja yang pernah mendengar sekaligus membaca tentang HIV AIDS. Seperti pernyataan informan berikut ini.

“mendengar HIV AIDS pada saat sekolah SMP kelas tiga. pernah juga melihat di televisi dan poster"(I-01)

“iya pak saya pernah mendengar HIV AIDS pada waktu SMP dikelas dua ada sosialisasi dari mahasiswa KKN”(I-04).

kemudian dari 8 informan remaja hanya sebagian kecil yang pernah mendengar dan membaca tentang HIV AIDS. Berikut pernyataan dari informan. 
“ iya pak saya pernah mendengar HIV dan membaca buku pada waktu SMP kelas dua"(I-02)

"saya Pernah membaca sekaligus mendengar HIV AIDS pada waktu SMP”(I-03)

Sementara itu hasil wawancara mendalam dengan informan pendukung dari tiga kepala sekolah yang berbeda tentang kebijakan bagaimana bentuk pencegahan HIV AIDS dikalangan remaja diperoleh penyataan informan bahwa penyembaran informasi HIV AIDS di lingkungan sekolah dilakukan oleh guru satu tahun sekali pada saat penerimaan siswa baru disaat pengenalan lingkungan sekolah, pihak sekolah juga biasanya mengundang instansi dari luar seperti, dinas kesehatan, kepolisian dan lain-lain, berikut pernyataan dari ketiga informan.

“Kebijakan yang sekolah lakukan dalam pencegahan perilaku HIV AIDS, melakukan sosialiasi kepada anak- anak kami baik di dalam kelas maupun mengundang instansi dari luar seperti dinas kesehatan, puskesmas yang sekolah lakukan setiap satu tahun sekali pada saat penerimaan siswa baru. Kegiatan tersebut sekolah lakukan pada saat pengenalan lingkungan sekolah atau yang sekolah kenal dengan istilah PLS”(IKP01).

"Untuk saat ini HIV AIDS tidak masuk dalam kurikulum pendidikan tetapi masuk kedalam beberapa materi terkait masalah penyakit menular atau jenis-jenis penyakit atau penyakit-penyakit masyarakat"khususnya kami yang di sekolah kesehatan (IKP01).

Dari hasil wawancara mendalam dengan petugas kesehatan tentang bagaimana bentuk penyebaran HIV AIDS dikalangan remaja sekolah diperoleh pernyataan dari petugas kesehatan mengatakan bahwa secara khusus belum pernah dilakukan sosialisasi HIV AIDS pada remaja, berikut pernyataan informan.

"Penyebaran informasi HIV AIDS di Puskemas Parigi secara khusus pada remaja belum pernah dilakukan, karena puskesmas memiliki terget yang diberikan oleh pihak Dinas Kesehatan. Adapun target yang diberikan oleh dinas kesehatan kepada pihak puskemas yaitu HIV pada ibu hamil, penderita TBC, Waria, dan tahan lapas"(IPKM01).

“ Pihak puskesmas hanya mengadakan sosialisasi kepada sekolah sekolah yang sudah ada kerja sama berupa MOU misalnya,SMP Negeri 1 Parigi, SMP 2 Parigi dan SMA Negeri 1 Parigi, adapun kegiatan yang dilakukan Puskesmas Seperti 
pemeriksaan berkala, penjaringan, pembagian tablet $F E$ pada remaja wanita dan lain-lainnya. kemudia Pihak puskesmas bisa turun kesekolah yang tidak ada kerja sama dengan melihat situasi serta kondisi angaran yang dimiliki oleh puskesmas"(IPKM-01).

\section{Pengertian HIV AIDS}

Berdasarkan hasil wawancara yang peneliti lakukan ke 8 informan remaja sebagian besar informan mempunyai persepsi yang hampir sama mengenai pengertian HIV AIDS yaitu adalah penyakit yang menular yang menyerang sistem imun/kekebalan tubuh manusia yang disebabkan karena hubungan seksual. terlihat pada kutipan berikut.

“menurut saya HIV AIDS itu penyakit menular. Penyebab dari HIV AIDS itu karena berhubungan seksual dengan pengidap HIV AIDS ., menurunya imunitas tubuh dan cepat sakit”. (I-01).

"HIV virus yang menyerang sistem imum manusia. Penyebab HIV AIDS adalah seks bebas berganti ganti pasangan seksual, serta penggunaan jarum suntik”(I-03)

"HIV itu virus yang menyerang sistem kekebalan tubuh Penyebab HIV itu karena seks bebas, jarum suntik, penggunaan narkoba."(I-04)

Selain itu terdapat dua informan remaja yang memiliki persepsi bahwa pengertian HIV AIDS adalah penyakit kelamin berikut kutipan hasil wawancara sebagai berikut.

"HIV AIDS itu virus yang menyerang alat kelamin manusia terutama itu pada perempuan karena berhubungan bebas"(I-05)

“HIV AIDS sejenis penyakit kelamin penyebabnya karena hubungan seks bebas”.(I- 06)

\section{Penyebab HIV AIDS}

Persepsi remaja tentang penyebab HIV AIDS dari 8 informan sebagian besar mempunyai persepsi yang sama bahwa penyebab HIV AIDS adalah virus, pergaulan bebas serta berhubungan seksual secara bebas. berikut terlihat kutipan wawancara dari informan.

"menurut saya Penyebab dari HIV AIDS itu sendiri karena berhubungan seksual dengan pengidap HIV AIDS”.(I-O1)

"Penyebab HIV AIDS adalah seks bebas berganti ganti pasangan seksual, serta penggunaan jarum suntik”.(I-03)

“Penyebab HIV itu karena seks bebas, jarum suntik, penggunaan narkoba.”(I-04)

"penyebab dari HIV ini adalah akibat dari pergaulan bebas “.(I-07) 


\section{Cara Penularan HIV AIDS}

Berdasarkan hasil wawancara dengan remaja cara penularan HIV AIDS dari diperolah hasil bahwa sebagain besar remaja mengatakan bahwa penularan HIV AIDS melalui hubungan seksual yang bergantian, penggunaan jarum suntik, darah dan lewat asi, selain itu ada beberapa remaja mengatakan bahwa penularan HIV AIDS bisa lewat bakteri dan pakaian yang kotor. seperti pernyataan remaja sebagai berikut ini.

“Bisa menular menular karena ganti-ganti pasangan”(I-04)

“menular melalui darah, jarum suntik yang sama, kemudian lewat Asi”(I-05).

“HIV AIDS itu bisa menular melalui jarum suntik, hubungan seksual”.(I-06)

Sementara itu beberapa informan remaja mengatakan bahwa cara penularan HIV AIDS bisa menular karena faktor keturunan, bakteri serta pakaian yang kotor. Berikut pernyataan informan.

"HIV AIDS itu penyakit yang bisa menular cara penularannya itu bisa dari GEN keturunan”. (I-01)

"HIV AIDS bisa menular lewat darah, lewat bakteri-bakteri yang menempel pada kulit”.(I-03)

\section{Pencegahan HIV AIDS}

Berdasarkan hasil wawancara mendalam dengan remaja tentang pencegahan HIV AIDS diperolah hasil sebagaian besar remaja memiliki jawaban yang bervariasi seperti, menjaga pergaulan, stop seks bebas, mencari informasi tentang HIV AIDS, dan lainnya, seperti pernyataan remaja sebagai berikut ini.

"menurut saya pencegahan HIV AIDS dengan mengubah pola dalam perilaku menjaga pola hidup sehat, serta mencari informasi tentang HIV AIDS”.(I-01)

“Stop yang namanya seks bebas”.(I-03)

“jangan suka ganti-ganti pasangan serta jajan di luar”.(I-04)

“membatasi pergaulan supaya tidak terkena HIV”.(I-06)

\section{Sikap Remaja Terhadap HIV AIDS}

Sikap remaja terhadap HIV AIDS peneliti uraikan diantaranya yaitu : waspada dalam pergaulan, persepsi remaja terhadap ODHA, serta remaja bersedia ikut aktif Sosialisasi HIV AIDS. 


\section{Waspada dalam pergaulan}

Berdasarkan hasil wawancara mendalam dengan remaja diperoleh hasil bahwa remaja merasa takut, sehingga remaja lebih berhati hati terhadap HIV AIDS serta menjaga pergaulan. Berikut pernyataan remaja.

"Lebih berhati-hati terhadap penyakit HIV AIDS, dan menjahui lingkungan yang buruk" (I-01)

"Setelah saya tau tentang HIV, respon saya lebih berhati-hati dan tidak melakukan hal yang bisa menyebabkan HIV AIDS"(I-03)

\section{Persepsi Remaja Terhadap ODHA}

Mengenai persepsi remaja terhadap ODHA, dari hasil wawancara mendalam remaja mengatakan bahwa akan tetap berteman tetapi menjaga jarak, berikut penyataan informan.

"Saya akan selalu berteman pak, tetapi saya akan menjaga jarak. karena tali sirahturami akan tetap dijaga meskipun dia punya penyakit” (I-02).

"ya kita harus bersikap biasa saja,jangan sampai membuat mereka tersinggung, dan masih tetap berteman namun di batasi."(I-04).

"Sikap saya akan membatasi pergaulan dengan dia pak,Tapi jangan dijahui.tetap berteman tapi tidak terlalu dekat"(I-07)

\section{Remaja bersedia ikut aktif Sosialisasi HIV AIDS}

Dari hasil wawancara mendalam dengan remaja diperoleh hasil bahwa semua remaja menjawab bersedia ikut aktif melakukan sosialisasi khususnya dikalangan remaja agar remaja lebih tahu tentang penyakit HIV AIDS. seperti pernyataan dari informan berikut ini..

"saya Bersedia, karena remaja khususnya agar mengetahui jangan sampai kena $H I V ”(I-01)$.

“bersedia, karena karena saya ingin menjaga diri saya dan lingkungan saya terhadap virus HIV AIDS”(I-02).

“Bersedia,supaya memberitahu orang tentang HIV AIDS”(I-05)

“bersedia agar masyarakat teredukasi untuk menjahui penularan penyakit ini”(I-07).

\section{Persepsi Norma Subjektif Remaja Terhadap HIV AIDS}

Persepsi norma subjektif remaja tentang HIV AIDS terdiri atas Persepsi Masyarakat tentang HIV AIDS, dampak sosial HIV AIDS di masyarakat, bayangan penyakit HIV AIDS serta pengaruh orang tua dan guru.

\section{Persepsi Masyarakat Tentang HIV AIDS}

Pandangan remaja tentang persepsi HIV AIDS dimasyarakat merupakan pernyakit yang berbahaya serta penyakit yang menular. berikut pernyataan dari informan. 
"menurut saya pak, pengetahuan masyarakat tentang HIV masih sangat minim karena kurangnya edukasi HIV AIDS di masyarakat. adanya persepsi dimasyarakat bahwa penyakit HIV AIDS penyakit kutukan akibat pergaulan bebas"(I-02).

"Penilaian masyarakat tentang HIV sangat berbahaya serta orang yang HIV bisa dikucilkan dimasyarakat sebagai penyakit kutukan karena pergaulan yang salah"(I03).

"pandangan masyarakat merasakan takut ngeri dengan penyakit HIV AIDS itu penyakit yang tidak mengenal usia biasa siapa saja yang terkena kalau misalnya dari mereka melakukan sex"(I0-6).

Remaja lain juga mengatakan bahwa masyarakat memiliki pengetahuan yang minim tentang HIV AIDS, sehingga terkadang mengabaikan penyakit HIV AIDS. Seperti pernyataan berikut

"masyarakat pengetahuannya masih kurang sehingga masyarakat kurang peka dan kurang respon terhadap HIV AIDS sampai saat ini kejadian HIV AIDS itu semakin bertambah"(I-07).

"masyarakat pada umumnya HIV itu belum banyak yang tau, ada beberapa yang tau dimasyarakat namun masih ada yang terkena HIV terkadang mereka mengabaikan"(I-08).

\section{Dampak Sosial HIV AIDS Di Masyarakat}

Berdasarkan hasil wawancara mendalam dengan remaja tentang dampak sosial HIV AIDS di masyarakat, remaja mengungkapkan bahwa pandangan masyarakat terhadap penderita HIV AIDS akan dikucilkan serta dijauhi karena penyakit HIV AIDS bisa menular. berikut pernyataan dari informan.

"Kayaknya di masyarakat kalau ada yang kena HIV pasti dibicarakan pak kesana kemari, artinya dikucilkan kerena kena HIV”(I-01).

"Dampak sosial tentunya masyarakat akan menjadi takut karena takut akan tertular dari penyakit HIV AIDS(I-O2).

“akan dijauhi oleh masyarakat karena HIV AIDS bisa menular”(I-05)

“dampak sosialnya pasti akan dijahui masyarakat dan dikucilkan karena masyarakat tidak mau tertular HIV”(I-O7).

"dimasyarakatkan belum semuanya tau tentang HIV AIDS biasa orang yang terkena HIV AIDS di masyarakat akan dijahui begitu pak karena kalau disentuh bisa menular pak, padahal belum tentu seperti itu pak"(I-08). 


\section{Bayangan Penyakit HIV AIDS}

Dari hasil wawancara mendalam remaja mengatakan bahwa apabila seseorang terkena penyakit HIV AIDS akan mudah sakit, susah untuk disembuhkan serta menyebabkan kematian.

“kalau sudah terkena HIV sepertinya susah untuk disembuhkan, dan juga penyakit ini bisa menyebabkan kematian kerena penyakit ini berbahaya dan juga belum ada obatnya"(I-02).

"Kalau didengar dari cerita-cerita orang cukup berbahaya, sampai bisa meninggal”(I03).

"Seperti saya dengar dimasyarakat, penyakit yang berbahaya, belum ada obatnya, itukan virus, dan menyerang sistem kekabalan tubuh"(I-04).

\section{Pengaruh Orang Tua Dan Guru}

Dari hasil wawancara mendalam dengan remaja tentang bagaimana pengaruh orang tua dan guru dapat memberikan dampak positif, remaja mengatakan bahwa sebagaian besar orang tua dan guru memiliki pengaruh yang baik/positif dalam bertindak agar tidak berisiko tertular penyakit HIV AIDS. Berikut Pernyataan informan.

"pengaruh orang tua Sangat besar sekali mempengaruhi saya dalam bertindak, karena orang tua merupakan payung dari keluarga"(I-02).

"pengaruh orang tua maupun teman sangat besar pak,karena mereka tau bahwa virus HIV itu sangat berbahaya bagi kita diri sendiri dan orang lain, saya yang paling sering saya dengar itu guru,guru yang paling sering menasihati”(I-04)

"Kalau orang tu besar sekaliOrang tua, karena stiap hari setiap saat orang tua memberikan nasehat seperti menjaga pergaulan, jangan dulu pacaran, serta dampaknya jika nanti itu terjadi”(I-05).

\section{Kontrol Perilaku Remaja terhadap HIV AIDS}

. Dalam penelitian persepsi remaja terhadap kontrol perilaku remaja HIV AIDS ini peneliti uraikan beberapa sub tema sebagai berikut menjaga perilaku berisiko HIV AIDS, Perilaku yang sudah dilakukan agar tidak berisiko HIV AIDS, mengontrol diri dari resiko HIV AIDS.

\section{Menjaga Perilaku Berisiko HIV AIDS}

Dari hasil wawancara mendalam dengan remaja diperoleh pernyataan yang berbeda dalam menjaga perilaku berisiko HIV AIDS. berikut ini pernyataan dari informan. 
“membatasi pergaulan”(I-02)

"Bergaul dengan orang - orang yang positif atau yang baik, yang bergaul tidak lewat batas, menjaga jarak serta tau batasan dalam bergaul”(I-03).

“Menjaga pergaulan,, mencari lebih banyak informasi tentang HIV AIDS”(I-04).

"Saya akan menjauh dari sekelompok orang pergaulannya sangat bebas dan menjahui tempat-tempat PSK”(I-07).

\section{Perilaku Yang Sudah Dilakukan Agar Tidak Berisiko HIV AIDS}

Dari hasil wawancara mendalam tentang persepsi remaja terhadap kontrol perilaku HIV AIDS, diperoleh pernyataan bahwa semua remaja mengatakan sudah melakukan tindakan yang berbeda-beda agar tidak berisiko HIV AIDS. berikut pernyataan informan.

“perilaku yang sudah saya lakukan untuk terhindar dari penyakit ini yaitu menjauhi pacaran,menjauhi pergaulan bebas juga,dan membatasi pergaulan”(I-04).

"Menjauh dari pergaulan yang salah, kemudian saya mencari pergaulan yang sehat, mencari informasi tentang HIV AIDS, serta menjaga diri”(I-06).

“menghindari pergaulan yang buruk, menuruti perkataan orang tua, serta mencari informasi informasi berkaitan dengan HIV" (I-08).

\section{Mengontrol perilaku resiko HIV AIDS.}

Dari hasil wawancara mendalam tentang persepsi remaja terhadap kontrol perilaku HIV AIDS, diperoleh pernyataan kontrol perilaku remaja tentang HIV AIDS. berikut pernyataan informan.

"selalu berdampingan dengan orang-orang yang positif, kemudian lingkungan yang baik, serta menyaring informasi yang diberikan kepada orang lain”(I-01).

"Kurangi keluar malam, kemudian lebih mendekatkan diri sama tuhan, dan menuruti nasehat orang tua”(I-04)

"cara saya mengontrol diri mungkin lebih mencari kegiatan yang positif, lebih banyak menghabiskan waktu bersama keluarga serta bekerja untuk memenuhi kebutuhan keluarga"(I-08).

Dari hasil wawancara mendalam dengan salah satu orang tua remaja tentang bagaimana pola asuh orang tua terhadap anak agar dapat mengontrol perilaku HIV AIDS. Orang tua mengatakan bahwa mereka selalu mendidik anaknya, memberikan nasehat, menjaga serta 
mengontrol pergaulan anaknya agar tidak salah pergaulan sehingga terhindar dari perilaku HIV AIDS. Berikut pernyataan informan.

"secara umum mendidik anak diusia remaja itu memang relative sulit karena usia remaja sangat rentan terpengaruh dengan pergaulan bebas serta lingkungan cara mereka bergaul sering secara besar masih salah. secara pribadi saya mendidik dengan memberikan masukan positif, mengarahkan membatasi pergaulan dan mendidik mereka cukup ketat dan perlu pengawasan ekstra”(IORT-01).

“Kalau terkait dengan HIV AIDS selaku orang tua akan memberikan informasi itu dan mungkin ketika kita belum sempat memberikaan informasi itu bias saja mereka di sekolah sudah diberikan informasi tentang HIV AIDS oleh gurunya"(IORT-01).

\section{PEMBAHASAN}

\section{Pengetahuan Remaja Tentang HIV AIDS}

Pada penelitian ini, peneliti memperoleh hasil dimana sebagain besar dari remaja pernah mendengar informasi tentang HIV AIDS yang diberikan oleh guru maupun dari kegiatan sosialisasi yang dikuti oleh para remaja. Namun sebagian kecil dari remaja pernah mendengar informasi tentang HIV AIDS serta pernah membaca tentang HIV AIDS.

Selain keterpaparan informasi HIV AIDS pada remaja,pada penelitian ini juga diperoleh hasil tentang pengetahuan remaja terhadap HIV AIDS dimana remaja sebagian besar memiliki pengetahuan yang cukup tentang pengertian HIV AIDS, penyebab HIV AIDS, cara penularan serta pencegahan HIV AIDS. Remaja belum mengetahui secara jelas pengertian HIV dan AIDS, penyebab dan cara pencegahannya. Remaja memiliki pengetahuan yang cukup karena mereka belum pernah mendapatkan informasi secara jelas terkait HIV AIDS di sekolah, dan kurang minat membaca artikel atau buku terkait. Mereka hanya sekadar tahu namun tidak terlalu paham secara rinci terkait HIV AIDS.

Pengetahuan ialah hasil dari tahu kemudian ini terjadi sesudah orang melakukan penginderaan terhadap salah satu objek. Penginderaan bisa terjadi berdasarkan panca indra yang dimiliki oleh manusia, yaitu indera penglihatan, pendengaran, penciuman, rasa, dan raba. Sebagian besar pengetahuan manusia diperoleh melalui mata dan telinga. Pengetahuan merupakan domain yang sangat penting dalam membentuk perilaku individu (17).

Pengetahuan tidak hanya diperoleh dari pendidikan formal saja, tetapi juga dapat diperoleh dari pendidikan non formal. Pengetahuan terhadap suatu objek mengandung dua aspek yang terdiri dari aspek positif dan aspek negatif. Kedua aspek dapat menentukan sikap seseorang 
individu. Apabila semakin banyak aspek positif yang diperoleh maka dapat menimbulkan sikap semakin positif terhadap objek tertentu (6).

Pengetahuan sangat erat berkaitan dengan sumber informasi, dimana sumber informasi yang banyak akan memberikan masukan pengetahuan yang baik pula sehingga seseorang tahu akan bahaya dari HIV AIDS dan akan melakukan upaya pencegahan HIV AIDS. Sumber informasi yang cukup memberikan pengetahuan yang baik kepada seseorang namun meskipun pengetahuan yang baik tetapi seseorang cenderung tetap melakukan tindakan yang berpotensi membuatnya tertular HIV, hal ini disebabkan oleh tidak adanya kesadaran dan rasa takut akan terjangkit virus HIV AIDS. Sumber informasi memberikan pengaruh pada pengetahuan seseorang, meskipun seseorang memiliki pengetahuan yang rendah namun jika mendapatkan sumber informasi yang banyak dari berbagai sumber maka hal tersebut dapat menambah pengetahuan seseorang.(24).

Informasi dapat di artikan sebagai segala sesuatu yang bisa memberikan tambahan pengetahuan dan wawasan kepada seseorang atau banyak orang, untuk mendapatkan suatu kebenaran yang ingin dicarinya dalam suatu informasi. Sumber informasi merupakan segala informasi yang diperoleh seseorang untuk mendapatkan apa yang dia cari dan didapatkan dari segala arah. Media promosi kesehatan yaitu saluran (channel) untuk menyampaikan informasi kesehatan.(22).

Hasil penelitian diatas terkait pengetahuan remaja tentang HIV AIDS sejalan dengan penelitian yang dilakukan oleh tentang Pengetahuan siswa-siswi Madrasah Aliyah Negeri Sidoarjo mengenai HIV AIDS mayoritas dalam kategori cukup yakni sebesar 44,8\%. Ratarata responden tidak mengetahui pertanyaan dasar terkait HIV AIDS seperti definisi, gejala awal, dan bagaimana virus HIV AIDS dapat menyerang tubuh. Pengetahuan responden tergolong sangat kurang dikarenakan mereka tidak pernah mendapatkan materi terkait HIV AIDS.(21).

Berdasarkan hasil penelitian tentang hubungan keterpaparan media terhadap pengetahuan dan sikap remaja tentang kesehatan reproduksi diperoleh hasil sebagian besar remaja mendapatkan informasi tentang kesehatan reproduksi bersumber pada Guru yaitu sebesar (82,3\%), Media Elektronik (72,6\%), Orang Tua (51,6\%) dan Media Cetak $(64,5 \%) .(11)$.

Masih kurangnya akses akan informasi tentang HIV AIDS yang benar pada remaja jika remaja tidak mendapatkan informasi yang benar mengenai HIV AIDS maka dikhawatirkan 
remaja akan coba-coba mencari sendiri dan dapat terpengaruh oleh informasi yang tidak tepat baik dari teman sebayanya maupun lingkungan sekitarnya. Jika keterpaparan sumber informasi remaja mengenai HIV/AIDS kurang maka pengaruh teman sebaya yang bersifat negative akan memberikan pengaruh yang cukup besar pada perilaku pencegahan HIV AIDS (20).

Pernyataan diatas sejalan dengan Penyebab terjadinya HIV AIDS pada masa remaja adalah remaja yang menjadi pecandu narkoba khususnya pengguna jarum suntik, kurangnya pengetahuan tentang informasi mengenai kesehatan reproduksi, seks bebas, HIV AIDS serta infeksi lainnya yang ditimbulkan oleh hubungan seks. Kurangnya informasi yang diperoleh remaja tentang kesehatan reproduksi berdampak pada pengetahuan kesehatan reproduksi mereka . Keterpaparan sumber informasi berpengaruh terhadap perilaku pencegahan HIV AIDS hal ini membuktikan bahwa keterpaparan sumber informasi sangat berperan dalam perubahan perilaku pencegahan HIV AIDS. Pengetahuan komprehensif remaja mengenai HIV AIDS saat ini masih kurang. Kurangnya informasi dapat menyebabkan remaja dapat mengalami resiko HIV AIDS dan juga berbagai pemikiran serta sikap negatif terhadap orang dengan HIV AIDS.(25).

Pengetahun menjadi faktor yang sangat penting dalam pembentukan perilaku individu baik positif maupun negatifnya perilaku seseorang sangat dipengaruhi oleh tingkat pengetahuan. Hal ini sejalan dengan hasil penelitian dikarenakan responden yang memiliki pengetahuan yang baik mempunyaki perilaku positif terhadap kontrol perilaku

HIV AIDS. Begitu pula pada responden yang memiliki pengetahuan cukup memiliki perilaku negatif terhadap kontrol perilaku HIVAIDS(16).

\section{Sikap Remaja Terhadap HIV AIDS}

Penelitian tentang sikap remaja terhadap HIV AIDS diperoleh hasil bahwa remaja memiliki sikap yang positif terhadap HIV AIDS. Hal ini ditunjukan dengan pernyataan remaja yang mengatakan akan selalu berhati-hati dan menjahui perilaku yang berisiko HIV AIDS.

Sikap merupakan ungkapan perasaan seseorang terhadap objek yang disukai atau yang tidak disukai baik itu positif maupun negatif. sikap juga merupakan hasil dari suatu proses psikologis, oleh karena itu sikap tidak bisa diamati secara langsung, tetapi harus disimpulkan dari apa yang dikatakan atau yang dilakukan.(15).

Remaja dengan sikap positif yang baik memiliki tingkat perilaku yang baik. Sikap sangat erat kaitannya dengan tingkat pengetahuan suatu individu. Sikap seseorang terhadap 
suatu objek menunjukan tingkat pengetahuan orang tersebut terhadap suatu objek. Keterpaparan sumber informasi berpengaruh terhadap perilaku pencegahan HIV AIDS hal ini membuktikan bahwa sumber informasi sangat berperan penting dalam perubahan perilaku pencegahan HIV AIDS.(17).

Faktor-faktor yang dapat mempengaruhi sikap remaja pengalaman pribadi, kebudayaan, orang lain yang dianggap penting, media massa, lembaga pendidikan dan lembaga agama. Pengalaman pribadi merupakan dasar pembentukan sikap dan sikap akan mudah terbentuk jika melibatkan faktor emosional. Kebudayaan mempengaruhi pembentukakan sikap, tergantung pada kebudayaan tempat individu tersebut dibesarkan. Orang lain yang dianggap penting umumnya individu memiliki sikap searah dengan orang yang dianggap penting dalam hidupnya. Media massa alam merupakan perantara yang membawa pesan sugestif yang dapat mempengaruhi opini sehingga dapat membentuk sikap tertentu. Lembaga Pendidikan dan Lembaga Agama berfungsi meletakkan dasar pengertian sikap dan konsep moral dalam diri individu sehingga ikut berperan dalam menentukan sikap. Sikap belum merupakan suatu tindakan atau aktivitas, tetapi predisposisi terjadinya perilaku (27).

Sikap menjadi faktor yang paling penting terhadap kontrol perilaku HIV AIDS sebagian besar remaja memiliki sikap terhadap pencegahan HIV AIDS pada kategori mendukung dengan perilaku positif terhadap pencegahan perilaku HIV AIDS.

Berdasarkan Theory of Planned Behavior sikap terhadap perilaku ditentukan oleh keyakinan terhadap konsekuensi yang timbul dari suatu perilaku yang ditampilkan.Ajzen menyatakan bahwa belief dapat diungkapkan dengan menghubungkan suatu perilaku dengan berbagai manfaat atau kerugian yang mungkin diperoleh apabila kita melakukan atau tidak melakukanperilaku itu.(21).

Penelitian ini sejalan dengan penelitian yang sudah pernah dilakukan oleh (10), Pengetahuan dan Sikap Siswa SMA tentang HIV AIDS di SMU Negeri I Wedi Klaten diperoleh hasil penelitian tentang sikap remaja terhadap HIV AIDS menunjukkan sebagian sebanyak $(85,7 \%)$ remaja mempunyai sikap positif dalam pencegahan HIV AIDS.

Dari beberapa hasil penelitian diatas sejalan dengan Teori Planned Behavior.(3). Sikap mempengaruhi intensi. keinginan seseorang untuk melakukan sesuatu dipengaruhi apakah seseorang memiliki penilaian positif atau memiliki penilaian negatif . Sementara itu (14) menyatakan seseorang yang memiliki sikap positif yang baik memiliki tingkat praktik yang 
baik.Sedangkan mereka yang memiliki sikap positif yang buruk menunjukan praktik yang buruk.

Sikap positif dan negatif merupakan suatu kecenderungan untuk menyetujui atau menolak. Sikap positif akan terbentuk apabila rangsangan yang datang pada seseorang memberi pengalaman yang menyenangkan. Sebaliknya sikap negatif akan timbul, bila rangsangan yang datang memberi pengalaman yang tidak menyenangkan. Sikap dapat ditumbuhkan dan dikembangkan melalui proses belajar. Dalam proses belajar tidak terlepas dari proses komunikasi dimana terjadi proses transfer pengetahuan dan nilai. Jika sikap merupakan hasil belajar, maka kunci utama belajar sikap terletak pada proses kognisi dalam belajar siswa, serendah apapun tingkatan proses kognisi siswa dapat mempengaruhi sikap.Tingkat pengetahuan yang rendah dapat mempengaruhi sikap, tetapi pengaruhnya sangat lemah serta sikap cenderung labil. Proses kognisi yang dapat menumbuhkan dan mengembangkan sikap secara signifikan.(3).

\section{Persepsi Norma Subjektif Remaja Terhadap HIV AIDS}

Penelitian tentang persepsi norma subjektif remaja terhadap HIV AIDS diperoleh hasil bahwa remaja memiliki persepsi norma subjektif yang positif terhadap HIV AIDS. Hal ini ditunjukan dengan pernyataan remaja yang mengatakan adanya pengaruh yang positif atau tekanan dari orang tua maupun guru serta teman sebaya dalam mempengaruhi remaja untuk menjaga serta mengontrol perilaku yang dapat menyebabkan HIV AIDS.

Persepsi norma subjektif remaja merupakan pandangan seseorang individu terhadap tekanan sosial yang ada di lingkungannya untuk melakukan atau tidak melakukan perilaku yang dipertimbangkan berhubungan dengan keputusan normatif yang dirasakan perilaku. Norma subyektif mengacu terhadap adanya suatu tekanan sosial yang dirasakan oleh seseorang untuk melakukan atau tidak melakukan perilaku. Norma subjektif menjadi keyakinan normatif yang berkaitan dengan persepsi individu tentang bagaimana suatu kelompok melihat perilaku dan mengevaluasi pada umumnya diperlihatkan sebagai motivasi individu untuk mematuhi kelompok-kelompok tertentu (3).

Hasil penelitian ini sejalan dengan Penelitian tentang The Role of Parents in the Prevention of HIV AIDS Among Secondary School Students in Ijebuode Ogun State, Nigeria menyimpulkan bahwa peran orang tua dalam mencegah HIV AIDS tidak dapat diremehkan. Orang tua

harus

menjadi panutan dan melatih anak-anak mereka dalam mengetahui langkah-langkah pencegahan yang aman terhadap HIV AIDS dan penyakit menular lainnya(23). 
Penelitian tentang upaya perilaku preventif remaja terhadap HIV AIDS berdasarkan theory of planned behavior (TPB) (Studi di Madrasah Aliyah Negeri Sidoarjo) diperoleh hasil mayoritas siswa memiliki norma subyektif yang baik terkait menghindari perilaku seksual beresiko yaitu sebesar $50 \%$, mayoritas responden setuju dengan pernyataan yang melibatkan orang terdekatnya seperti orang tua dan teman dekat beranggapan bahwa menghindari perilaku seksual beresiko merupakan perbuatan yang baik (20).

Seseorang yang dianggap berpengaruh dalam penelitian ini adalah orang tua, guru, dan teman sebaya. Ketiga orang ini memiliki peran penting dalam mempengaruhi niat remaja untuk menghindari perilaku seksual beresiko HIV AIDS. Hal ini sesuai dengan penyataan bahwa perilaku seksual remaja lebih besar dipengaruhi oleh perilaku seksual teman sebaya selama masa remaja awal sampai dewasa awal .(4).

Norma subjektif menjadi fungsi keyakinan individu dalam hal menyetujui atau tidak menyetujui perilaku tertentu. Menyetujui atau tidak menyetujui suatu perilaku, didasari oleh suatu keyakinan yang dinamakan dengan keyakinan normatif Faktor lingkungan keluarga merupakan orang yang dapat mempengaruhi tindakan individu, seorang individu akan melakukan atau berperilaku apabila persepsi orang lain terhadap perilaku tersebut bersifat positif. Individu mempersepsikan bahwa perilaku individu tersebut diperbolehkan atau sebaliknya. Hubungan sikap terhadap perilaku sangat menentukan, maka norma subjektif juga dipengaruhi oleh keyakinan, bedanya adalah apabila hubungan sikap terhadap perilaku merupakan fungsi dari keyakinan terhadap perilaku yang akan dilakukan (behavioral belief) maka norma subjektif adalah fungsi dari keyakinan seseorang yang diperoleh atas pandangan orang-orang lain yang berhubungan dengannya (normative belief) (16).

\section{Persepsi Kontrol Perilaku Remaja terhadap HIV AIDS}

Penelitian tentang persepsi kontrol perilaku remaja terhadap HIV AIDS diperoleh hasil bahwa remaja memiliki persepsi kontrol perilaku yang positif terhadap HIV AIDS. Hal ini ditunjukan dengan pernyataan remaja yang mengatakan akan menjaga, menghindari dan juga remaja sudah melakukan kontrol perilaku yang dapat menimbulkan risiko HIV AIDS.

Seorang individu memiliki kontrol perilaku atas dasar kemauan diri sendiri secara penuh. Ajzen menyatakan perilaku seseorang tergantung pada keinginan berperilaku (behavioral intention) yang terdiri dari beberapa komponen, diantaranya sikap (attitude), norma subjektif (subjective norm), dan pengendalian perilaku yang dirasakan (perceived behavioral control). Sementara munculnya perilaku,karena adanya niat untuk berperilaku 
tertentu dari suatu individu. Niat itu sendiri juga tidak akan muncul tanpa adanya determinan yang mempengaruhi (18).

Penelitian tentang upaya perilaku preventif remaja terhadap HIV AIDS berdasarkan theory of plann ed behavior (TPB) (Studi di Madrasah Aliyah Negeri Sidoarjo) diperoleh hasil sebanyak $(55,1 \%)$ remaja memiliki kontrol perilaku yang positif untuk menghindari seksual berisiko HIV AIDS (20).

Kontrol perilaku dalam Theory of Planned Behavior, dipersepsikan sebagai suatu keyakinan mengenai ada atau tidaknya berbagai faktor yang memfasilitasi atau menghalangi dalam menampilkan suatu perilaku tertentu.Keyakinan ini dapat didasari oleh pengalaman masa lalu, tetapi juga bisa dipengaruhi oleh informasi yang didapat dari orang lain. Selain itu juga dipengaruhi oleh faktor lain yang meningkatkan atau menurunkan persepsi mengenai kesulitan untuk menampilkan suatu perilaku tertentu. Seseorang perilaku karena dipengaruhi oleh intensi atau niat, dan kontrol aktual individu untuk menampilkan atau tidak menampilkan perilaku tersebut. Niat yang mendasari tersebut dapat dipicu oleh beberapa faktor yaitu sikap terhadap perilaku, norma subyektif, dan kontrol perilaku yang dirasakan. Ketiga faktor tersebut dapat muncul dari faktor personal seperti persepsi, faktor sosial seperti usia, jenis kelamin dan tingkat pendidikan, juga dapat dipicu oleh faktor informasi yaitu pengetahuan.(2)(3)

Theory of planned behavior merupakan alat yang dapat digunakan untuk memprediksi perilaku individu ketika individu tersebut tidak memiliki kontrol kemauan sendiri secara penuh. Individu tersebut memiliki halangan atau hambatan sehingga perilakunya tidak bisa semaunya sendiri. Perilaku merupakan respon atau reaksi seseorang terhadap stimulus. Namun dalam kenyataan, stimulus yang diterima oleh seseorang tidak selamanya mampu menghasilkan perilaku, ada beberapa faktor lain yang berperan dalam munculnya perilaku, salah satunya adanya niat untuk berperilaku tertentu dari suatu individu. Niat itu sendiri juga tidak akan muncul tanpa adanya determinan yang mempengaruhi. Keinginan berperilaku menunjukkan berapa banyak usaha individu ingin berkomitmen untuk melakukan perilaku dengan komitmen yang lebih tinggi dengan kecenderungan perilaku itu akan dilakukan. Keinginan untuk berperilaku ditentukan oleh sikap dan norma subyektif. Sikap mengacu pada persepsi individu (baik menguntungkan atau tidak menguntungkan) terhadap perilaku tertentu. Norma subjektif mengacu pada penilaian subjektif individu tentang preferensi lain dan dukungan untuk berperilaku.(17). 
Theory of Planned Behavior didasarkan pada persepsi bahwa manusia adalah makhluk yang rasional dan menggunakan informasi-informasi yang mungkin baginya, secara sistematis. Orang memikirkan implikasi dari tindakan mereka sebelum mereka memutuskan untuk melakukan atau tidak melakukan perilaku-perilaku tertentu.(5).

Persepsi kontrol perilaku dapat berubah tergantung situasi dan jenis perilaku yang akan dilakukan. Pusat kendali berkaitan dengan keyakinan individu bahwa keberhasilannya melakukan segala sesuatu tergantung pada usahanya sendiri persepsi kontrol ditentukan oleh keyakinan individu mengenai ketersediaan sumberdaya berupa peralatan, kompatibilitas, kompetensi, dan kesempatan (control belief strength) yang mendukung atau menghambat perilaku yang akan diprediksi dan besarnya peran sumber daya tersebut (power of control factor) dalam mewujudkan perilaku tersebut. Keyakinan yang kuat terhadap tersedianya sumberdaya dan kesempatan yang dimiliki individu berkaitan dengan perilaku tertentu dan semakin besar peranan sumberdaya tersebut maka semakin kuat persepsi kontrol individu terhadap perilaku(14).

\section{KESIMPULAN DAN SARAN}

Pada penelitian ini remaja memiliki pengetahuan yang kurang tentang HIV AIDS karena kurangnya akses informasi yang diperoleh remaja serta kurangnya minat remaja dalam mencari tahu tentang HIV AIDS, sementara itu remaja memiliki sikap, persepsi norma subjektif dan kontrol perilaku yang positif terhadap HIV AIDS. Saran yang dapat diberikan diharapkan kepada pihak terkait seperti petugas kesehatan, guru dapat memberikan informasi yang lebih efektit tentang HIV AIDS sehingga dapat meningkatkan pengetahuan remaja.

\section{DAFTAR PUSTAKA}

1. Aisyah, S., \& Fitria, A. (2019). Hubungan Pengetahuan dan Sikap Remaja tentang HIV/AIDS dengan Pencegahan HIV/AIDS di SMA Negeri 1 Montasik Kabupaten Aceh Besar. Jurnal Bidan Komunitas, 2(1), 1. https://doi.org/10.33085/jbk.v2i1.4081

2. Ajzen, I. (2005). Attides, Personallity and Behavior. In International Journal of Strategic Innovative Marketing (Vol. 3, pp. 117-191).

3. Ajzen, I. (2020). The theory of planned behavior: Frequently asked questions. Human Behavior and Emerging Technologies, 2(4), 314-324. https://doi.org/10.1002/hbe2.195

4. Apsari, A. R., \& Purnamasari, S. E. (2018). Hubungan Antara Konformitas Dengan Perilaku Seksual Pranikah Pada Remaja. Insight: Jurnal Ilmiah Psikologi, 19(1), 1. 
https://doi.org/10.26486/psikologi.v19i1.596

5. Buess, M. (2012). Metastasiertes nierenzellkarzinom: Heutige therapeutische optionen. Tagliche Praxis, 53(1), 51-58.

6. Damanik, A. T. (2021). Hubungan tingkat pengetahuan dengan perilaku upaya pencegahan hiv/aids pada siswa sma negeri 1 raya dan sma swasta gkps raya skripsi.

7. Dhungel, B. A., Shrestha, N., \& U-Dhungel, K. (2013). Perception and knowledge about HIV/AIDS among Nepalese adolescent. Janaki Medical College Journal of Medical Science, 1(2), 32-39. https://doi.org/10.3126/jmcjms.v1i2.9266

8. Dinas Kesehatan Provinsi Sulawesi Tengah. (2019). Profil Kesehatan Provinsi Sulawesi Tengah Tahun 2019. https://doi.org/10.1007/978-3-8349-9424-0

9. Hamilton, C. (2014). The nature of visuospatial representation within working memory. Spatial Working Memory, January 2011, 122-144 https://doi.org/10.4324/9781315793252

10. Handayani, S. (2011). Pengetahuan Dan Sikap Siswa Sma Tentang Hiv/Aids Di Smu Negeri I Wedi Klaten. Kemampuan Koneksi Matematis (Tinjauan Terhadap Pendekatan Pembelajaran Savi), 6(9), 1689-1699.

11. Isnaeni Rofiqoch. (2017).Hubungan Keterpaparan Media Terhadap Pengetahuan Dan Sikap Remaja Tentang Kesehatan Reproduksi, 53(9), 1689-1699.

12. Kesehatan RI, P. D. K. (2018). Info Datin HIV AIDS 2018.

13. Machrus, H., \& Urip, P. (2010). Behavioral Measurement based on Theory of Planned Behaviour. Insan Media Psikologi, 12(01), 64-72. https://doi.org/10.1002/ejoc.201200111

14. Mahyarni, M. (2013). Theory Of Reasoned Action Dan Theory Of Planned Behavior (Sebuah Kajian Historis Tentang Perilaku). Jurnal El-Riyasah, 4(1), 13. https://doi.org/10.24014/jel.v4i1.17

15. Mayssara A. Abo Hassanin Supervised, A. (2014). Paper Knowledge . Toward a Media History of Documents, Ajzen, 1-20.

16. Moutong, J. P. (2018). Dinas Kesehatan Parigi Moutong. Profil Kesehatan Kabupaten Parigi Moutong Tahun 2018, 1-10.

17. Nugrahawati, R. E. P. C. (2018). Faktor-Faktor Yang Mempengaruhi Perilaku Remaja Terhadap Pencegahan HIV/AIDS Di SMA Negeri 2 Sleman Tahun 2018. Skripsi.

18. Nugrahawati, R. E. P. C., Hernayanti, M. R., Purnamaningrum, Y. E., \& Petphong, V. (2019). Factors related to adolescent behavior in HIV/AIDS prevention. Kesmas, 13(4), 195-201. https://doi.org/10.21109/kesmas.v13i4.2698

19. Nurwati, N., \& Rusyidi, B. (2019). Pengetahuan Remaja Terhadap Hiv-Aid. Prosiding Penelitian Dan Pengabdian Kepada Masyarakat, 5(3), 288. https://doi.org/10.24198/jppm.v5i3.20607

20. Rahmah, R. M. (2017). Upaya perilaku preventif remaja terhadap HIV \& AIDS berdasarkan theory of planned behavior (TPB). Jurnal Ilmiah Kebidanan, 3(1), 1-12. http://journal.stikespemkabjombang.ac.id/index.php/jikeb/article/view/45

21. RahmanT, E. Y. (2014). Faktor-Faktor Yang Mempengaruhi Perilaku Pencegahan HIV/AIDS Pada Remaja. Dinamika Kesehatan. Vo.13.No.13., 13(13 Juli 2014), 8093. https://ojs.dinamikakesehatan.unism.ac.id/index.php/dksm/article/view/195 
22. Rini, A. S., \& Noviyani, E. P. (2019). Konfirmasi Lima Faktor yang Berpengaruh terhadap Perilaku Remaja dalam Pencegahan HIV/AIDS. Jurnal Ilmiah Kebidanan Indonesia, 9(04), 138-153. https://doi.org/10.33221/jiki.v9i04.407

23. Science, C. S. (2013). The Role of Parents in the Prevention of Hiv / Aids Among Secondary School Students in Ijebuode Ogun State, Nigeria. Canadian Social Science, 9(2), 7-8. https://doi.org/10.3968/j.css.1923669720130902.7269

24. Solihati, \& Faridah, I. (2020). Pengetahuan Dan Sikap Tentang Hiv / Aids Dan Upaya Pencegahan Hiv / Aids. Jurnal Kesehatan, 9(1). https://doi.org/10.37048/kesehatan.v9i1.129

25. Suarnianti, S., \& Haskas, Y. (2021). Penguatan Intervensi Perilaku terhadap Pencegahan HIV pada Kelompok Berisiko: Sistematik Review. Jurnal Kesehatan Andalas, 9(4), 439 https://doi.org/10.25077/jka.v9i4.1431

26. UNAIDS. (2018). UNAIDS Data 2018. Global Report On The Global AIDS Epidemic Date, 1-376.

27. Zuchdi, D. (1995). Pembentukan Sikap (Teori Reasoned Action). Jurnal Cakrawala Pendidikan, 3(3), 51-63. 